\title{
VEDÓ Attila \\ A Magyar Királyi Csendőrség \\ közlekedési szolgálati ágának kialakulása és fejlődése
}

A XIX. század végére Európa csaknem minden nagyvárosában megjelentek a benzin- vagy petróleum üzemủ robbanómotorral felszerelt automobilok, mint a haladás és a jövő hírnökei. Magyarországon a századforduló előtt indult meg a gépi meghajtású jármüvek közlekedése, amely néhány évtized alatt a vidéki területeken is a mindennapok részévé vált. A közlekedés rendjének megszervezése és fenntartása, valamint az egyre növekvő számú közúti balesetek megelőzése érdekében szükségessé vált az állami fellépés. A vidéki területeken a feladat a Magyar Királyi Csendőrségre, mint a rendért és a biztonságért általánosan felelős katonailag szervezett fegyveres örtestületre hárult és a két világháború közötti időszakra önálló szolgálati ág kialakulásához vezetett.

\section{A magyarországi automobil-közlekedés kezdetei}

Budapesten 1895-ben jelent meg az első „motorkocsi”, melyet nagy érdeklődés övezett és közlekedésére inkább szenzációként tekintettek, mint szabályozandó területre. A közlekedési szabályok alapjait és ezek megszegésével megvalósuló kihágásokat ekkor a közutakról és vámokról szóló 1890. évi törvény rendelkezései tartalmazták. Az évtizedeken keresztül változatlan alapvetés is itt került megfogalmazásra, vagyis a „balra hajts, balra térj ki, jobbról elözz."1 A technikai fejlődés azonban komplexebb szabályozást igényelt és önálló közlekedési rendelet kiadását sürgette.

A szaporodó automobilok az államigazgatás figyelmét is felkeltették. 1897-ben DÁNIEL Ernő kereskedelemügyi miniszter állást foglalt a szabályozás tárgyában, mely szerint a benzin- és petróleummotorok üzemeltetésének hatósági felügyelete szükségtelen, mivel azok az általános tapasztalatok szerint nem veszélyesek. Az állami vezetés később belátta a gépjármü-közlekedés szabályozásának szükségét, azonban az automobilok alacsony száma csak Budapesten tette szükségessé külön szabályok megalkotását. A XX. század első évtizedében már az országos közlekedési rend iránti igény is felmerült, melyet az 1909. X. 11-én Párizsban aláírt nemzetközi egyezmény alapján 1910-ben kiadott belügyi rendelet ${ }^{2}$ szabályozott. A rendelet a gépjármüvek forgalmát, müszaki vizsgálatát, rendszámmal való ellátását, a gépjárművezetők képzését, valamint a nemzetközi forgalomban való részvétel feltételeit szabályozta. Az első állami soföriskola 1912-ben nyitotta meg kapuit.

1926-ban Párizsban újabb közlekedésrendészeti tárgyú nemzetközi egyezmény megkötésére került sor, melyet hazánkban az 1929-ben foglaltak törvénybe. ${ }^{3}$ Ennek végrehajtási utasítása volt a belügyi tárca rendeleteként jelent $\mathrm{meg}^{4}$, amely Közlekedési Kódex néven vált ismertté.

A kódex hatályba lépéséig közel negyven közlekedési tárgyú rendeletben került szabályozásra a közutak forgalma. Ezeket foglalta egységes szerkezetbe az 1930. I. 1-vel hatályba lépett új jogszabály. A kisebb jelentőségü rendeletek hatályon kívül helyezése mellett az úttörvény és a gépjármüvek közúti forgalmáról szóló 1910. évi belügyminiszteri rendelet egyes részei érvényben maradtak. A kódex hatálya kiterjedt a közforgalmú utakon közlekedő valamennyi gépjármüre, állati és emberi erővel vont kocsira, kerékpárosokra, gyalogosokra, valamint az úton hajtott állatokra. Az utak fenntartásáról és mü-tárgyainak védelméről szóló szabályopzás azonban továbbra is úttörvényben, a gépjármüvek nemzetközi forgalmáról szóló rendelkezések pedig az 1910. évi belügyi rendeletben szerepeltek. A kódex rendelkezései nem vonatkoztak a közutakon elhelyezett vasutak forgalmára és a vasúti pályákon való gyalogos közlekedésre. ${ }^{5}$

A kódex körüli kezdeti vitás kérdések rendezésére a belügyminiszter és a kereskedelemügyi miniszter közös értelmező rendeletet adott ki, amely a mindennapi életben felmerülő gyakorlati problémákhoz igazította a jogértelmezést. Ez gyakorlatilag a vicinális és közdűlő utakon könnyített a kódex szigorán és a mezőgazdasági munkák kapcsán enyhébb szabályokat írt elő. ${ }^{6}$ A területi hatály tehát továbbra is az úttörvényhez nyúlt vissza, amely az utakat hat csoportba osztotta azok fontossága alapján. Ezek az államutak, a törvényhatósági utak, az előbbieket a legközelebbi vasútállomással összekötő utak, a községi közlekedési (vicinális) utak, a tisztán községi (közdülő) utak, valamint a magánosok és társaságok által létesített közforgalmú utak (magánutak). ${ }^{7}$

Összességében tehát a kódex a szabályozottságot az utak forgalmának sürüségéhez igazította, ami segítette az új rendre történő átállást és a mezőgazdasági munkákhoz kapcsolódó áruszállítást.

Bár a harmincas évekre az utakon fordultak elő a legnagyobb számban a nem természetes halálesetek, és a közlekedési balesetek $60 \%$-a vidéki utakon történt, külön intézkedések csak a legjelentősebb országutakon történtek a közlekedési rend fenntartására. Útijáröröket szükség esetén valamennyi csendőr örs vezényelhetett szolgálatba, ez azonban legtöbbször a közbiztonsági szolgálat 
rovására történt és így nem lehetett rendszeres. A balesetek számának növekedése határozott intézkedéseket kívánt az állami vezetéstől. Ekkor már mintegy 16000 autó és hozzávetőlegesen 10 000 motorkerékpár közlekedett az ország útjain. ${ }^{8}$ A Magyar Királyi Csendőrség ekkor kapta feladatul a vidéki utak forgalmának közlekedési kódex szerinti ellenőrzését, valamint a balesetek visszaszorítását. Az első közlekedési őrsök megalakulásakor a testületben nem alkalmaztak gépjármüveket napi szolgálati feladatokra, így mind a jármüvek beszerzése, mind a személyi állomány felkészítése új feladatként jelentkezett. A Magyar Királyi Csendőrség - mint alapvetően gyalogos szolgálatot ellátó testület - tehát hátrányos helyzetből indulva kezdte meg a közlekedési rend megteremtését.

\section{A Közlekedési szakterület fejlődése}

A közlekedési csendőrség felállítását a korszak közigazgatási gondolkodására jellemző felkészülés és előre tervezés elvei határozták meg. A közlekedési kódex hatályba lépését megelőzően mind a szükséges eszközök és jármüvek beszerzéséről, mind pedig a leendő személyi állomány kiképzéséről intézkedtek. 1928. IX. 4-től 1929. IV. 28-ig a kiválasztott 20 fö csendört a honvédséghez vezényeltek, ahol gépjármüvezetői tanfolyamon vettek részt. A tanfolyam végén a csendőrök motorkerékpár, személygépkocsi és tehergépkocsi vezetésére jogosító igazolványt is kaptak, amely az adott korszakban komoly szakképesítésnek számított.

1929 őszén szerezték be az első motorkerékpárokat a szakterület számára: három $1000 \mathrm{~cm} 3$-es Méray oldalkocsis, és hat $500 \mathrm{~cm} 3$-es Méray szóló motorkerékpárt. Ezek közül 1-1 oldalkocsis és 3-3 szóló motorkerékpárt az új őrsök, a harmadik oldalkocsis jármủvet a nyomozó osztály „motortisztje”, mint a szakterületet felügyelő kikülönített szaktiszt kapta.' (I.sz. melléklet)

A közlekedési szakterület alapjait a székesfehérvári és győri őrsökön fektették le, melyek az ország legnagyobb forgalmú útjain kezdték meg müködésüket. Legénységük 6 fő volt a kezdeti időszakban. A székesfehérvári őrs a Budapestre vezető főutat csak a székesfehérvári kerület határáig felügyelte, később azonban egészen Budafokig, vagyis a fővárosi rendőrség müködési területének határáig. A Balaton körüli Székesfehárvár-Balatonfüred-Keszthely, valamint a Székefehérvár-SiófokKeszthely főtakat $300 \mathrm{~km}$ hosszan ez az őrs ellenőrizte. A győri őrs a Hegyeshalom-Győr-KomáromNyergesújfalu-Piliscsaba-Budapest útvonalat ellenőrizte $180 \mathrm{~km}$ hosszan. Ez az út akkoriban Európa egyik legjobb minőségü autóútja volt, ahol problémamentesen közlekedhettek a gépjármüvek 90-100 kilométeres óránkénti sebességgel.

1930. IV. 1-től 1930. VI. 30-ig 19 fö önként jelentkezőt Székesfehérvárra vezényeltek három hónapos gépjárművezetői tanfolyamra a budapesti közlekedési őrs felállításának előkészületeként. A tanfolyam parancsnoka ORENDY Norbert százados volt, aki motortant, műhelyszolgálatot, gyakorlati vezetést és a közlekedési kódex ismereteit tanította. Az elsősegélynyújtást BERTICS Gyula főorvostól, a csendör kerület orvosfőnökétől tanulták. Az 1930. VI. 28-án megtartott vizsgán SCHILL Ferenc tábornok, a csendőrség felügyelöje elnökölt. Az elméleti és gyakorlati vizsgákon a hallgatók kiválóan szerepeltek. A felkészítés ekkor már saját erőből, a honvédség igénybevétele nélkül történt, ami szintén a korabeli előrelátás kifizetődését mutatja. Még 1929-ben négy $350 \mathrm{~cm} 3$-es szóló motorkerékpárt is beszerzett a testület a szolgálatra kiadott jármüveken kívül, melyek közül kettő a későbbi saját szervezésü tanfolyamok oktatójármüve lett. ${ }^{10}$

Az 1931-ben megszervezett budapesti közlekedési őrs felállításakor már figyelembe vették a megszerzett tapasztalatokat és kizárólag oldalkocsis motorkerékpárokkal látták el a legénységet. Az őrs a Böszörményi úti csendőrlaktanyába települt. 1931 március és április hónapjaiban a budapesti őrs legénységét oktatóutakra vitte a leendő müködési területre a szakterület meghatározó alakja, KONTRA Kálmán százados. Az őrs járőrei először 1931. V. 13-án indultak szolgálatba. Négy héten belül több mint 100 feljelentést tettek. ${ }^{11}$ A székesfehérvári út kivételével a budapesti őrs ellenőrzése alá került a fóvárosba futó összes foút, vagyis Nyergesújfalu felől $60 \mathrm{~km}$, Vác felől $30 \mathrm{~km}$, Hatvan felől $60 \mathrm{~km}$, Cegléd felől 70 km, Örkény felől pedig 70 km, vagyis összesen 300 km.

A közlekedési örsök további szervezése a rossz gazdasági viszonyok miatt 1936-ig megrekedt, amikor a Balkán és a Mátra felé vezető utak felügyeletére felállították a kecskeméti és mezőkövesdi örsöket.

A motoros legénység öltözete és felszerelése az első években problémákat okozott. A tollas csendörkalapról annak tekintélye miatt nem szívesen mondott le az állomány, azonban a hosszabb távú müködés tapasztalatai ellene szóltak. Többek között akadályozta a motoros szemüveg használatát és nem nyújtott kellő védelmet a téli menetszél és az eső ellen. A közlekedési járőr számára éppen ezért célszerüségi okokból napellenzős tollas sapkát rendszeresítettek. A speciális feladatrendszer miatt a felszerelések és a fegyverzet átgondolása is szükségessé vált. Az oldalkocsis motorkerékpárral szolgálatot teljesítő járőrpár felszerelése eltért egymástól. A vezető pisztollyal, az oldalkocsiban helyet 
foglaló csendőr pedig puskával volt felszerelve a gyalogos járőrrel megegyező felszereléssel. A puskát a csendőr hosszirányban az ölébe fektetve szállította, ami baleset esetén veszélyes lehetett. Már a korai időszakban felmerült annak gondolata, hogy a közlekedési csendőröket kizárólag pisztollyal és kard helyett gumibottal lássák el. Az oldalkocsiban ülő csendőr esőben magára gombolhatta a kocsi vízhatlan takaróvásznát, a vezető ruhája azonban a nem védte meg viselőjét az esőtől. Felmerült a bőrruházat vagy bőrköpeny gondolata is a vezető részére. ${ }^{12}$ A felszerelések és a ruházat folyamatos fejlődése egyre inkább a gyakorlati igényekhez közelítető formaruhát eredményezett, ebből fakadóan egy évtized múltán a közlekedési csendőrök már korszerü motoros ruházattal rendelkeztek. (II.sz. melléklet)

Az őrsök szolgálatellátásának növekvő színvonala és a személyi állomány korszerüsödő felszerelése mellett a közlekedési szakterület vezetési rendszere is jelentős fejlődésen esett át néhány év leforgása alatt. A szolgálati ág kezdetben a nyomozó osztály-parancsnoksághoz tartozott, így költséghatékonyabban kezdhette meg müködését. A megtakarított összegeket a fejlesztésbe és képzés-be fektették.

1929-től 1932. VIII. 1-ig a motortiszt volt felelős a közlekedésrendészeti ügyekért. Ezt követően az I. csendőr kerület gépjármü előadója vette át a feladatokat, melyeket egészen 1936.VI. 15-ig, az első igazi közlekedési tiszti parancsnokság felállításáig végzett. Ez a Nyomozó Osztály-parancsnokság alárendeltségében megszervezett Közlekedési és Híradó Alosztály volt. 1939. I. 15-én az alosztály két szolgálati ága elkülönült és önálló alosztályokként müködtek tovább. ${ }^{13}$

1937-ben a Magyar Királyi Csendőrség szolgálati szabályzata alapján általánosságban szolgálatot teljesítő közlekedési csendőrök külön szolgálati utasítást kaptak, így szervezetük és felszerelésük mellett alapvető szabályzójuk is a specializáció felé hatott. ${ }^{14}$

1938-ban Jánosházán, Debrecenben, Miskolcon, Dunaföldváron és Szolnokon állítottak fel új örsöket. Előre számolva ezzel 1937-ben 20 Fiat Balilla kisgépkocsit szereztek be. ${ }^{15}$ (III.sz. melléklet) A budapesti őrsöt ezzel párhuzamosan három Steyr 50 típusú gépkocsival erősítették meg. (IV.sz. melléklet)

1939-ben a Felvidék visszacsatolásával megszervezésre került a kassai, az ungvári és a huszti örs, 1940-ben a bajai, körmendi és gyulai örsöket állították fel.

1940. III. 1-ével létrehozták a Magyar Királyi Csendőrség Közlekedési és Híradó Osztályát. Az osztály egy híradó, egy repülőtéri és három közlekedési szárnyból állt (Budapest, Komárom és Ungvár székhellyel), melyeket egy müszaki alosztály szolgált ki. ${ }^{16}$ A közlekedési szárny-parancsnokok feladatai megegyeztek az azonos szintü parancsnokok feladataival, azonban nekik évente kétszer a más alegységekhez használatra kiadott gépkocsikat is ellenőrizniük kellett. ${ }^{17}$ Ugyancsak 1940-ben állították fel a vasúti csendőrséget a fokozódó jelentőségü vasúti hadiszállítások biztosítására.

1941-ben Besztercén, Kolozsváron és Újvidéken hoztak létre új örsöt. Az örsök száma így már 19-re nőtt. 1942-ben Balassagyarmaton, Székelyudvarhelyen és Désen települtek új őrsök, ezzel párhuzamosan megkezdte müködését a dési közlekedési szárny-parancsnokág is. A megváltozott prioritások miatt egyes őrsök díszlokációt váltottak: a gyulai őrs Szegedre, a bajai Kaposvárra, a debreceni Nagyváradra, a besztercei Szeretfalvára költözött. ${ }^{18}$

A négy közlekedési szárny így 22 örssel, örsönként 7-9, országosan 201 fö közlekedési csendőrrel látta el szolgálati feladatait. A budapesti szárnyhoz tartozott a siófoki vízirendészeti őrs is. A testület egészéhez mérten a szakterület a dinamikus fejlődés ellenére is szerény méretü maradt. A repülötéri szárny például három szakasszal és 19 örssel, összesen 212 fö csendőrrel látta el feladatait, ${ }^{19}$ ami vetekedett az országosan megszervezett közlekedési csendőrséggel.

A szerény létszám ellenére azonban a közlekedési szakterület testesítette meg a szervezet csaknem teljes mobilitási képességét, hiszen a közlekedési őrsökön kívül csak a magasabb parancsnokságok rendelkeztek gépkocsikkal. A terület-visszacsatolások idejére az ország területén 38 osztály, 80 szárny, 193 szakasz és 1375 őrs müködött. Ebböl 11 vasúti, 11 vízi, 11 híradó, 19 repülötéri és 22 közlekedési őrs. A gépjármủvel ellátott őrsök száma azonban csupán 1,5 \% volt. A gépjármübeszerzéseknek köszönhetően 1936-tól évente mintegy 30 db gépjármủvel gyarapodott a testület, így 1943-ra már 500 gépjármü volt a szervezet hadrendjében. ${ }^{20}$

A terület-visszacsatolások és a háborús előkészületek újabb feladatok elé állították a szolgálati ágat. Ezek egyrészt új szervezeti elemek létrehozását és a tevékenység megszervezését jelentették ott, ahol addig nem volt közlekedési csendőrség, másrészt a felvonuló alakulatok számára a forgalomirányítást és a települő csendőr-parancsnokságok gépjármüvel történő ellátását.

A Magyarországhoz visszacsatolt területeken a testület 2 kerületet, 33 szárnyat, 70 szakaszt és 500 örsöt állított fel, emellett a fokozottan veszélyesnek tartott térségekben, Kárpátalján és Bácskában 
külön nyomozó részlegeket is létrehozott. A speciális szervezetek kiépítése sem maradt el, így 23 különleges (közlekedési, híradó, vasúti és repülőtéri) örsöt is megszerveztek. ${ }^{21}$

A Felvidék közbiztonsági szolgálatának megszervezése céljából kirendelt csendőrségi szervezeti elemek megerősítésére 1939. I. 24-től 1939. V. 1-ig 10 közlekedési ôrs 24 gépkocsija és ezek legénységét vezényelték e feladat teljesítésére. Külön említést érdemel azonban, hogy Kárpátalja visszatérésekor már nem volt szükség a közlekedési szolgálati ág járműveire és személyi állományára. ${ }^{22}$ 1941-ben a Balkánra felvonuló német csapatok áthaladását is a közlekedési őrsök állománya biztosította.

A közutak rendjének fenntartása és a vasútrendészeti feladatok megszervezése után újabb közlekedési kötődésü speciális szolgálattal bővült a Magyar Királyi Csendőrség szakaszolgálatainak köre. A vízi csendőrséget 1942-ben szervezték meg, amely a Balatonon teljesen ki is épült. Tervezték müködési területének és szervezetének kiterjesztését a Dunára és a Tiszára is, ezt azonban a háború már nem tette lehetővé. ${ }^{23}$ (V.sz. melléklet)

Összességében elmondható, hogy az 1929-ben felállított közlekedési csendőrség folyamatos fejlödésen esett át az 1940-es évekig. A szakterület a kedvező tapasztalatok dacára csak 1939-re fejlödött önálló szakterületté. Az őrsök száma 1942-ig folyamatosan gyarapodott, a szolgálati ág vezetési szintjei és szervezettsége fejlődött. A közlekedési csendőrség alig több, mint 10 év alatt egy két őrsből álló „kísérleti” szakszolgálatból önálló és a testület sikeres működését nagyban elősegítő szolgálati ággá alakult, melynek szakmai elvei és tapasztalatai napjainkig meghatározzák a hazai közlekedésrendészet fejlődését.

\section{A csendőr általános és speciális közlekedésrendészeti feladatai}

A közlekedési járőr elsődleges feladata a közlekedési rend fenntartása, a közlekedési szabályok betartásának ellenőrzése, baleset esetén az elsősegély nyújtás és a sérültek kórházba juttatásáról való gondoskodás, valamint a baleseti helyszínelés volt. Fontos feladatként kezelték az eltévedt autósok útbaigazítását és a müszaki segélynyújtást is. Az utakon és azok közelében észlelt büncselekmények esetén a közlekedési járőr csak akkor intézkedett, ha a késedelem veszéllyel járt. ${ }^{24}$ Éppen ezért minden közlekedési csendőrnek tudnia kellett, hogy menetvonalán hol helyezkednek el csendör őrsök, melyeknek az elfogott jogsértést elkövető személyeket átadhatták.

Szolgálatba induláskor a közlekedési járör "Szolgálati Lap”-ot és „Gépjárómü menetlevelet” kapott. A szolgálati tevékenységet úgy határozták meg, hogy a pihenőket is beleszámítva 5 óra szolgálatra átlagosan $50 \mathrm{~km}$ leportyázott útszakasz jusson. A kezdeti időszakban a győri és székesfehérvári őrsök állománya ugyanannyi szolgálati órát teljesített, mint a gyalogos és lovas örsök járörei, ezt azonban a gépjármüvek kímélete és a karbantartási idő miatt csökkentették. A közlekedési járör a budapesti örs megalakulása után napi 5 óra szolgálatot teljesített, ami napi $50 \mathrm{~km}$, vagyis havi $1500 \mathrm{~km}$ megtételét jelentette. Az örs-parancsnok napi átlag 3 órát töltött az utakon és eközben $30 \mathrm{~km}-\mathrm{t}$ járt be. ${ }^{25}$

A járör megengedett legnagyobb sebessége $40 \mathrm{~km} / \mathrm{h}$, az ellenőrző őrs-parancsnoké $50 \mathrm{~km} / \mathrm{h}$ volt. A közlekedési járőr senkit nem üldözhetett, mivel ezzel a közlekedés többi résztvevőjét veszélyeztette volna. Ezt az ártatlanokat is veszélyeztető fegyverhasználattal vonták egy tekintet alá és szigorúan tiltották. A jelzésre meg nem álló vagy a baleset helyszínét elhagyó jármü rendszámát a járôr leolvasta és a legközelebbi telefon igénybevételével értesítette az útba eső őrsöket és a jármủ feltartóztatását kérte. ${ }^{26}$

A szakterület eredményei kimagaslóak voltak és folyamatos fejlődést tükröztek. 1932-ben 3 örsön 16 motorkerékpárral látták el szolgálatukat. 1933-ban a jármüvek száma nem változott, mégis évi 40000 kilométerrel, vagyis naponta átlagosan 100 kilométerrel több utat jártak be és ellenőriztek. 1935-ben változatlan jármúállomány mellett már 60000 kilométerrel több utat tettek meg 1933-hoz viszonyítva. A közlekedési állomány által feljelentett kihágások száma ezzel párhuzamosan az 1932-es 1816-ról 1935-ben 3682-re, 1938-ban pedig már 25 433-ra növekedett. ${ }^{27}$ 1942-re a szakterület már évi 100000 igazoltatást foganatosított, ami örsönként 5000-6000 föt, közlekedési csendörönként pedig közel 1000 föt jelentett. A közlekedési kihágások miatt felelősségre vont személyek száma évi 31 000-32 000 fő volt. ${ }^{28}$

A közlekedésrendészet nemcsak szervezeti struktúra kiépítését, felszerelés és gépjármüvek beszerzését követelte a csendőrségi testülettől, hanem azt is, hogy teljes személyi állománya felkészüljön a feladatkörében jelentkező, közlekedési vonatkozású feladatok hatékony végrehajtására. A speciális feladatú és képzettségü, de alacsony létszámú szakosított személyi állomány önmagában nem volt képes a közlekedés rendjét fenntartani, így valamennyi csendőrnek ismernie kellett a közlekedési ellenőrzések alapjait. A közlekedésrendészet körében jelentkező feladatok általános (bármely járôr által végrehajtott) és speciális (csak a közlekedési személyi állomány által végrehajtott) feladatokra oszthatók. A tényleges szolgálati feladatok három nagy csoportba rendezhetők, úgymint: 
1. forgalomirányítás és vonulással járó rendezvények biztosítása;

2. a közúti forgalom ellenőrzésére;

3. feladatok közlekedési baleset helyszínén.

Mindhárom feladatcsoportba tartoztak általános és speciális feladatok, melyeket célszerü feladatcsoportonként külön-külön áttekinteni.

1. A szakterület fennállása alatt folyamatosan bővülő körben és növekvő számban jelentkeztek olyan feladatok, melyek útvonalak lezárását, katonai alakulatok átvonulásának biztosítását, vagy felvonulások kísérését tették szükségessé. Ezeket javarészt speciális feladatnak tekintették és a közlekedési csendőrség hatáskörébe utalták, azonban bizonyos kiemelt események kapcsán gyalogos csendőrök is részt vettek bennük. Ilyen volt az 1933-as gödöllői cserkész világtáborozás biztosítása, vagy a „közlekedési irányváltás”. Magyarországon a közúti közlekedésben 1941-ben tértek át a bal oldaliról a jobb oldali közlekedésre: Budapesten 1941. XI. 9-én, Budapesten kívül már 1941. VII. 6án. Az átállás napjaiban a föútvonalakon a jelzőtáblák között járőrök álltak fel. Az irányváltó pontokon gyalogos járőrök, elöttük és mögöttük közlekedési járőrök segítették a forgalmat. ${ }^{29}$

2. A közúti forgalom ellenőrzése kapcsán összetettebb feladatok hárultak a csendörökre. A forgalomellenőrzés egyrészt a közlekedési szabályok betartásának ellenőrzéséből állt a járművek haladása során, másrészt a járművezetés személyi feltételeinek (vezetői igazolvány, orvosi vizsgálat, tanulási engedély, kiegészítő lap fuvarozáshoz, stb.) és a gépjármüre vonatozó müszaki üzemeltetési és adminisztratív feltételek (rendszám, igazoló lap, adóbélyeg, forgalmi engedély, stb.) ellenőrzéséből állt.

$\mathrm{Az}$ új közlekedési kódex hatályba lépését követően annak rendelkezéseiről tájékoztatták a lakosságot, ami vidéken legtöbbször a falu lakossága előtti felolvasást és elmagyarázást jelentette. ${ }^{30}$ Természetesen a szabályok megértéséhez és érvényre jutásához a csendőr segítő fellépésére és gyakran magyarázatára is szükség volt. A vicinális és közdülő utakon a forgalomellenőrzés legtöbbször e segítő szándékú figyelmeztetésben merült ki. Más volt azonban a helyzet a föutakon, ahol a személy- és tehergépkocsik ellenőrzése nagyobb felkészültséget és határozottságot igényelt. Az autók terjedésével a csendőrség vezetői megfigyelték, hogy míg a szélhámosok és gyorsan menekülni szándékozó bünözők egyre gyakrabban utaznak gépkocsin, addig a csendőr járőr az autó tekintélyéből fakadóan általában nem igazoltatja őket. Éppen ezért a szakirodalom ajánlásként fogalmazta meg valamennyi csendőrnek, hogy ne csak a jogsértés elkövetésén tetten ért gépkocsikat, hanem „kémpróbaszerủen” a közlekedő vagy éppen várakozó autókat és utasaikat is vonják rendészeti ellenőrzés alá. Ezt az idegen autók esetében mindig, az ismerősök esetében pedig időszakosan volt ajánlatos végrehajtani. Nemcsak a közlekedési járőr, hanem valamennyi csendőr ellenőrizhette, hogy a gépkocsivezetőnek van-e jogosítványa, eleget tett-e a kötelező orvosi vizsgálatnak és van-e három kitöltött betétlapja? Mivel az indok nélküli ellenőrzéseket kerülni kellett, az igazoltatás indokaként a gépkocsi és a vezető közlekedésre alkalmasságát, vagyis közvetve a személy- és vagyonbiztonság megóvását jelölték meg.

A gépkocsivezetők ellenőrzésekor számos szabályt és elöírást kellett figyelembe venni minden járörnek. A közlekedési szakszolgálat állományának speciális ismeretei elméletileg csak az ellenőrzések alaposságában és mélységében mutatkozhattak meg. A gépjármüvezető vonatkozásában a következőkre terjedt ki az ellenörzés:

- Rendelkezik-e a kerületi gépjárómühatóság által kiállított vezetői igazolvánnyal, melyet a közlekedés során magánál tart? A személygépkocsi vezetésére kiállított igazolvánnyal csak személygépkocsit, autóbuszt, vagy maximum $1500 \mathrm{~kg}$ hasznos terhelésü „üzleti kihordó járművet” lehetett vezetni. A motorkerékpár és tehergépkocsi jogosítványok szintén nem voltak érvényesek más jármükategóriára. A jogosítvány melléklete volt a betétlap, melyből legalább három kitöltött példányt a vezető magánál tartott. Jogsértés vagy baleset esetén a csendőr elvett egy betétlapot a gépkocsivezetőtől és kitöltötte a rendszámra vonatkozó rovatot.

- Rendelkezik-e a szükséges orvosi vizsgálatot igazoló, rendőrhatóság által kiadott könyvecskével, amely szintén a vezetői igazolvány függeléke volt? A hivatásos gépkocsivezetők évente, az úrvezetők háromévente voltak kötelesek az orvosnál jelentkezni.

- A gépkocsivezetés tanulására közterületen csak gyakorlási engedély birtokában és érvényes vezetői igazolvánnyal rendelkező kísérő felügyelete alatt volt lehetőség. Külön rendelkezések vonatkoztak a vizsgára szállított és kipróbálásra szánt gépkocsikra is.

- Az úrvezetők 18 éves korukig úgynevezett korengedéllyel belföldi forgalomban közlekedhettek, 18 évet betöltött gépkocsivezető nemzetközi forgalomban is részt vehetett, hivatásos soför 20 éves kortól, míg autóbuszvezető 22 éves kortól lehetett valaki. 
- Helyközi teherfuvarozásra a MÁV kapott engedélyt, melyet a Magyar Teherfuvarozók Országos Központi Szövetkezete (MATEOSz) útján valósított meg. A szövetkezetbe tömörült fuvarozók engedély-okmányában meg voltak jelölve a tevékenység földrajzi keretei és feltételei is. A teherfuvarozásra történő jogosultságot a MATEOSz által kiállított „Kiegészítőlap” igazolta. Az élő állatokat szállító tehergépkocsiknak ezen felül külön igazolványuk és forgalmi naplójuk is volt, melyet ellenőrzéskor be kellett mutatniuk. ${ }^{31}$

- A külföldiek Magyarország területén nem vezethettek gépjármüvet vezetői igazolvány nélkül. A külföldre utazó magyar soförök okmányait a Magyar Királyi Automobil Club állította ki és a rendőrhatóság láttamozta. A nemzetközi vezetői igazolvány egy évig volt érvényes. A nemzetközi útiigazolvánnyal külföldröl érkező gépjármüvek egyébként szabadon közlekedhettek, az okmány egyszerre igazolta a gépjármü és a gépjármüvezető megfelelését a hazai szabályoknak. ${ }^{32}$

A távolsági forgalomban közlekedő járómủvek vezetőinek és hajtóinak személyazonosításra alkalmas okmányokkal (pl. cselédkönyvvel, adóívvel) is rendelkezniük kellett. ${ }^{33}$

Ahogy napjainkban is, a gépkocsikat elsősorban a rendszámtábla azonosította. A rendszám a legrégebbi közlekedési igazgatási szabályok egyike, hiszen a bérkocsik számmal történő ellátását már I. Lipót is elrendelte 1663 -ban. ${ }^{34}$ A gépjármüvek rendszámtáblával történő ellátásának szabályozását a közúti forgalomban résztvevő gépjármüvek, pótkocsik megvizsgálása, új rendszámmal, igazolólappal ellátása s a közlekedésrendészeti egységes szabályzat egyes rendelkezéseinek módosítása tárgyában kiadott 1932. évi belügyi rendelet helyezte új alapokra. ${ }^{35}$ A rendelet a közúti forgalomban résztvevő összes gépjárművek megvizsgálása és újbóli nyilvántartásba vétele iránt intézkedett. Ezen megvizsgáláshoz a gépjármüvel együtt az illetékes rendőrkapitányságnál be kellett mutatni a gépjármü forgalmi engedélyét, igazolólapját és igazolni kellett az előirt díjak és adó megfizetését. Ez alkalommal az illető rendőrkapitányság a megvizsgált gépjármüvet új rendszámmal és igazolólappal látta el, a régieket pedig bevonta. A gépjárművekről ezzel új nyilvántartás készült.

Az addigi - elől 9x24 cm, hátul $15 \times 43 \mathrm{~cm}$ méretü — rendszámtáblákat mind alakjukban, mind tartalmukban megváltoztatta az új jogszabály. A 2 betüből és 5 számból álló azonosító jelet 2 betủre és 3 számra változtatta a könnyebb leolvashatóság érdekében. Az új rendszámtáblán lévő első betủ az illető gépjármükerület székhelyét, a második betủ pedig a gépjármü minőségét jelezte. Az ország területét 18 gépjármü-kerületre .osztották, melyek székhelytelepülései nevének a kezdőbetüi jelölték a rendszámon azt, hogy a gépjármü mely gépjármükerülethez tartozik. ${ }^{36}$

Mivel a nagy sebességgel haladó jármüvek rendszámát a külső szemlélő csak rövid ideig látta, az első rendszámon a betűk, a nagyobb méretü és megvilágított hátsó rendszámon a számok voltak az első helyen. A rendszám lehetett fehér alapon fekete vagy fekete alapon fehér kivitelü. A kutatások és elözetes kísérletek alapján a rendszer $25 \%$-kal növelte a rendszámok helyes leolvasásának valószínüségét. ${ }^{37}$

1933. X. 9-étől csak azok a gépjármüvek közlekedhettek közúti forgalomban, amelyek ezen a megvizsgáláson és újbóli nyilvántartásba vételen átestek. ${ }^{38} \mathrm{Az}$ új rendszámtábla akkor volt hiteles, ha a hátoldalán az „Országos Közlekedésrendészeti Bizottság” felirat látszott és a rajta szereplő számok megegyeztek az alvázszám első karaktereivel. Az elveszített rendszám helyett készített házilagos másolatot csak az elvesztés bejelentéséről szóló hatósági igazolással együtt lehetett elfogadni. A gépjármü-közlekedéssel kapcsolatos valamennyi igazolást a kerületi gépjárómühatóság állította ki, azokat a községi hatóságok által tévedésből vagy tájékozatlanságból kiadott iratok nem pótolták.

A gépkocsi azonosítását szolgálta még az igazolólap is, amely a kocsiszekrény oldalára volt erősítve egy zárt fémtokban. Ha a tulajdonos személye megváltozott a lapot a hatóság módosította, ezért az ideiglenesen nem volt a helyén. A lap hiánya nem volt szabálytalanság, de további vizsgálódást tett szükségessé. A tehergépkocsikon és pótkocsikon a tulajdonos nevét, foglalkozását és címét fel kellett tüntetni egy a felépítmény jobb oldalra erősített fehér alapon fekete színú táblán.

A gépjármü csak úgy vehetett részt a közúti forgalomban, ha közúti adóbélyeggel volt ellátva a szélvédő jobb oldalán vagy motorkerékpároknál az úgynevezett adótokban. Az adóbélyeg színe az érvényesség szerint változott: az éves piros, a negyedéves fehér, a havi zöld színű volt. A bélyeg hiányát csak az adóbélyeg kiváltáshoz szükséges adóhatósági utalvány ellenében lehetett elfogadni, ellenkező esetben a gépkocsit a községi elöljárósághoz kellett elővezetni. Itt a községi hatóság a rendszámtáblát leszerelte, jegyzőkönyvet vett fel és a gépkocsit a legrövidebb úton a telephelyére irányította. Az ettől való eltérés kihágás volt, melyre a csendőr szintén figyelmet fordított.

A forgalmi engedélyt a gépkocsivezető nem volt köteles magánál tartani, azonban ha rendelkezésre állt az ellenőrzéskor, a csendőrnek azt is meg kellett vizsgálnia. Az okmány „Hivatalos 
feljegyzések" rovatába jegyezték be a szállítható személyek számát vagy tehergépkocsinál a vontatható pótkocsik számát és jellegét.

A rendészeti ellenőrzést ajánlatos volt müszaki ellenőrzéssel is kiegészíteni, ha a csendőr kellően képzett volt az automobilok vonatkozásában. Elsősorban a lámpák működőképességét és a hátsó rendszámtábla megvilágítását kellett ellenőrizni. Ezen kívül az úgynevezett „mechanikai irányjelzö” elhelyezésére és lakott területen kívül a mentődoboz meglétére is ki kellett térni. A tehergépkocsikat és autóbuszokat visszapillantó tükörrel kellett felszerelni. A gumiabroncsok felületének szakadások és folytonossági hiányok nélkül simának kellett lennie. ${ }^{39}$

A fenti ellenőrzések során tapasztalt szabálytalanságok elkövetőit a csendőr figyelmeztette, feljelentette, vagy később ${ }^{40}$ - a külföldi példákhoz hasonlóan - helyszíni bírsággal sújtotta.

\section{Feladatok közlekedési baleset helyszínén}

Az általános és speciális közlekedésrendészeti feladatok a balesetek kapcsán különültek el leginkább. A gyalogos járör inkább a helyszín biztosítására, míg a közlekedési járőr föként a felelösség megállapításra és a bizonyítékok rögzítésére koncentrált.

$\mathrm{Az}$ általános gyakorlat szerint a baleset helyszínére érkező gyalogos járőr egyik tagja a sebesültekkel foglalkozott, a másik gondoskodott a nyomok megóvásáról és biztosította a helyszínt. A biztosító csendőr kiválasztotta a nézelődők vagy arra közlekedők közül az orvost, más állami alkalmazottat vagy szabadságos katonát, akit segítségnyújtásra hívott fel és adataikat feljegyezte. A tanúk kiválasztása után a csendőr számára érdektelen személyeket el kellett távolítani. ${ }^{41}$ Különösen meg kellett akadályozni, hogy a balesetben érintett gépjármúvekhez bárki hozzányúlhasson és megváltoztassa a sebességváltó állását, az irányjelző állapotát vagy megrongáljon fontos alkatrészeket és később müszaki hibára hivatkozzon. A súlyosabb sérülteket egy alkalmas jármüvel a legközelebbi kórházba irányították vagy e célból üzenetet küldtek valakivel az ôrsre. Ha a sérülések nem voltak súlyosak, akkor hatósági tanúk előtt ki is kellett hallgatni a sérülteket.

Ha közlekedési járőr érkezett a helyszínre vagy vette át az intézkedést, azonnal megkezdte a helyszíni szemlét. Tisztázta, hogy mi változott meg a helyszínen és miért, a talált nyomokat pedig pontosan felmérte és vázlaton ábrázolta. Ez a későbbi helyszínrajz elkészítéséhez volt szükséges.

A helyszín vizsgálatát a baleset tényleges helyszínének 100-500 méteres körzetében kellett elvégezni. A keréknyomok vizsgálata volt az első lépés, melyek irányát, folyamatosságát és mintázatát szemlélték meg. Ezt minél előbb el kellett végezni, mivel a forgalom továbbhaladásával ezek a nyomok megsemmisültek. A keréknyomokat a szakirodalom gurulási, fékezési, csúszási (farolási), és ütközési nyomokként különböztette meg. A keréknyomokat a baleset helyszínétől 50-100 méteres távolságig vizsgálták meg, hogy a gépkocsik mozgására és sebességére következtetni tudjanak.

A balesetben részes jármüvek vezetőinek és utasainak kikérdezése volt a következő lépés, ha azt állapotuk megengedte. Fontos volt a személyi adatok és a sérülések pontos rögzítése későbbi orvosi bizonyítvány beszerzése céljából. Ezt követte a tanúk kihallgatása, melyet azon a helyen kellett végrehajtani, ahol a baleset idején tartózkodtak. A kikérdezés alkalmával tanú jelenléte volt szükséges, mivel a csendör jegyzőkönyvet nem vett fel. A helyszíni kihallgatást azért tartották fontosnak, mert így az élmény még friss volt és a felelősség szempontjából érdekelt személyek sem tudták befolyásolni a vallomásokat. Minden tanút minden jármü, személy és más tanú helyzetére és valamennyi külső körülményre vonatkozóan ki kellett kérdezni. A tanúk elmondása alapján meg kellett állapítani a jármủ sebességét is, amely egy adott tereptárgytól a baleset helyszínéig tartó útszakasz megtételének idején alapult. A sebességet a járôr valószínúsítette a jármü tanú általi észlelésének helye és a balesetig történt eseményekhez szükséges idő alapján. Például a tanú 500 méterre látta meg a gépkocsit egy fa mellett és a baleset bekövetkezéséig 20 lépést tett meg. Ha a lépései tempóját a járőrnek bemutatta kiderült, hogy 25 lépést átlagosan fél perc alatt tett meg. Az időre vonatkozó kérdéseket a tanú személyiségéhez igazították, vagyis tisztázták, hogy a kérdéses időszakban mit mondott, honnan hová haladt, hányat szívott a pipájából, stb. A járőr ebből valószínüsítette a jármüvek sebességét. Természetesen a sértett és gyanúsított felet is kikérdezte a fentiekre, akiknek a járművek sebességére vonatkozó nyilatkozatait a fentiek tükrében vizsgálta meg.

Ha gyanú volt arra, hogy a balesetet okozó jármü vezetője ittas volt, annak fokát orvossal meg kellett állapíttatni és erröl bizonyítványt kérni. Ha a vezető ittasnak bizonyult, akkor az elindulása helyétől a balesetig megtett útját teljes hosszában be kellett járni, az ennek során történt eseményeket és tapasztalható körülményeket fel kellett deríteni. A kódex 4. $§ 1$. pontja szerint nem vezethetett járművet, aki alkoholt fogyasztott, így Olaszország után második európai államként hazánkban is tiltottá vált az ittas vezetés. Ha a csendőr ittas személyt ért tetten gépjármüvezetés közben, azt a 
csendőrségi szolgálati szabályzatának 312 . pont 11. vagy 12. alpontja szerint, mint személy- és vagyonbiztonságra veszélyes egyént elfogta. ${ }^{42}$

A korabeli szakirodalom komolyan foglalkozott a baleseti okokkal és azok minél körültekintőbb helyszíni megállapításával. Elsődleges baleseti okként számoltak a „pneumatik kilyukadásával”, vagyis a durrdefekttel, a gépjármüvezető nem megfelelő reakcióidejével és tapasztalatlanságával, valamint az ittas jármüvezetéssel. A további okok között a közlekedési szabályok súlyos megszegése, a gyorshajtás és a sportszenvedély is megjelent. ${ }^{43}$

A műszaki jellegủ kiváltó okok vizsgálatához elengedhetetlen volt a jármüvek müködésének és hibáinak, valamint a különböző felépítmények viselkedésének ismerete az ütközés során. Az autó szerkezetét, főként pedig kormányberendezését szakértővel kellett megvizsgáltatni, ha a csendőr nem tudta megállapítani, hogy az helyesen működött-e. Vizsgálni kellett, hogy a jármü karbantartottsága és felszerelése szabályszerủ volt-e és megterhelése is a megengedett értéken belül volt-e. A balesetet okozó gépkocsivezetőtől a betétlapot el kellett venni és a feljelentéshez csatolni. ${ }^{44}$

Ha a balesetet külső hatás, pl. kődobálás okozta azt is meg kellett állapítani, hogy a követ dobó személy hol állt és ezt a helyszínrajzon is jelölni kellett.

Ha valamely gépkocsi tulajdonosának nevét meg akarták állapítani a rendszám alapján, akkor 08.00 és 20.00 óra között a Budapesti Főkapitányság Közigazgatási Osztályát kellett megkeresni a 109-48 telefonszámon. Ha a baleset halált vagy súlyos testi sértést okozott, akkor azt a Btk. ${ }^{45} 291$. $\S$ vagy $310 \S$ szerint kellett minősíteni, könnyü sérülés esetén a Kbtk. ${ }^{46}$ 92-125. § szerinti kihágás miatt kellett eljárni. ${ }^{47}$

A közúti balesetekről készített feljelentések mellé csatolni kellett a sértett orvosi bizonyítványait, könnyü testi sértés esetén a nyilatkozatot, az ittas okozó orvosi bizonyítványát, erkölcsi és vagyoni bizonyítványt, a fiatalkorú okozó születési anyakönyvi kivonatát, a helyszínrajzot, valamint a betétlapot. ${ }^{48}$

Gyalogosok elütésénél (gázolásnál) a sértett testén is keresték a kocsi által hagyott nyomokat, hogy megtudják, a jármü melyik része érintkezett a személlyel. A baleset környezetében és a mütárgyakon gumikenődéseket, olajnyomokat, üvegcserepeket és vérnyomokat kerestek, melyek helyét pontosan feljegyezték. A későbbi eljáráshoz rögzíteni kellett a látási viszonyokat, időjárást, hőmérsékletet, az úttest állapotát és szélességét is. ${ }^{49}$

A csendőrség szolgálati szabályzatának 463. pontja szerint minden baleset helyszínéről helyszínrajzot kellett készíteni. A vázlatnak meg kellett felelnie a testület szolgálati szabályzata 12 . mellékletének és abból az utat, a tereptárgyakat, a balesettel kapcsolatos nyomokat és tárgyakat, az egyes személyek elhelyezkedését pontosan fel kellett ismerni. ${ }^{50}$ A helyszínrajzzal kapcsolatban három alapvető követelményt fogalmaztak meg: egyszerü legyen, vagyis csak a legszükségesebb tereptárgyakat tartalmazza, világos legyen, vagyis külső szemlélő is el tudja képzelni a történteket, és áttekinthető legyen, vagyis a világtájakat, távolságokat és a vázlat léptékét fel kellett tüntetni rajta. A vázlat elkészítéséhez az örs 1 : 75000 arányú munkatérképe szolgált alapul, melynek megfelelő részletéről a csendőr kivonatot rajzolt. Mivel a baleseteknél apró tárgyak vagy alkatrészek elhelyezkedése is fontos volt, az $1: 2500$ vagy még kisebb méretarányú vázlatok voltak a legjobban használhatók. Ha az esemény két település közötti úton következett be, akkor célszerü volt egy vázlaton két arányt alkalmazni, például a települések közötti útszakaszt $1: 2500$ arányban ábrázolni, de a baleset konkrét helyét középen kiemelve sokkal részletesebben $1 \mathrm{~cm}=10$ lépés arányban. A távolságokat méterben vagy lépésben kellett megadni. A fontos tárgyakat méreten felüli arányban kellett ábrázolni és megjegyzést füzni hozzájuk. A sérültek vagy halálos áldozatok pontos helyén túl a testhelyzetet is ábrázolni kellett egyszerü pálcikarajzokkal, melyekhez a jelmagyarázatban megjegyzést füzhettek. A jelmagyarázatot bonyolultabb esetekben a vázlat egyes elemeinek számozása vagy egyéb megjelölése után is össze lehetett állítani. ${ }^{51} \mathrm{Az}$ ekkor bevezetett egyezményes jelek és alkalmazott jelzések, valamint a helyszínrajz elkészítésének gyakorlati lépései napjainkig alig változtak.

Összességében elmondható, hogy a Magyar Királyi Csendőrség közlekedésrendészeti szolgálati ága megfelelt a vele szemben támasztott szervezeti és társadalmi elvárásoknak és sikerrel tette biztonságosabbá a közúti közlekedést hazánk vidéki útjain. Az 1920-as évek végére egyre nagyobb számban megjelenő gépi meghajtású jármüvek ellenőrzése fokozódó rendészeti igényt fogalmazott meg, melyet a csendőrség hangsúlyos szerepvállalással elégített ki. A közlekedési szolgálati ág a szervezet sokrétü feladatkörébe illeszkedve tette központilag szervezetté a közúti forgalom ellenőrzését és tevékenysége nyomán olyan eljárásrendek és szakmai alapelvek fogalmazódtak meg, melyek napjainkig fellelhetők a közlekedési balesetek helyszínén foganatosított intézkedésekben. 
Jegyzetek:

${ }^{1} 1890 /$ I.tc. $107 . \S$ a)

257 000/1910. (IV. 29.) BM.r.

3 1929/XXXII.tc

${ }^{4} 250$ 000/1929. (VIII. 8.) BM.r.

5300 166/1927. (XI. 8. ) BM.kr. ; 81 161/1929.BM.r. ; 1879/XL.tc. (Kbtk.) 112. §

${ }^{6}$ ÉLTHES: 46.p.

${ }^{7}$ A Gergely-féle autótérkép az ország útjait három csoportba sorolta: I. alépítménnyel ellátott mủút, II. alépítménnyel el nem látott müút, III. ki nem épített főbb út, amelyen a községek egymás közötti forgalma bonyolódott.

FÁBRY

${ }^{8}$ TOLDI: 306.p. 1933-as adat.

${ }^{9}$ FODOR II. rész 665.p.

${ }^{10}$ Loc.cit. I. rész

${ }^{11}$ Loc.cit. I. rész 637.p.

${ }^{12}$ Loc.cit. II rész 611.p. ; SzLADEK I. rész

${ }^{13}$ Loc.cit. II. rész 665.p.

${ }^{14}$ KUT-1937.

${ }^{15}$ FODOR: op.cit. I. rész 637.p.

${ }^{16}$ PARÁDI: A Magyar Királyi Csendőrség szervezete. ; PARÁDI: A magyar rendvédelem története.

${ }^{17}$ REKTOR 178-179.p.

${ }^{18}$ KONTRA: A közlekedési csendőrség két utolsó esztendeje.

${ }^{19}$ REKTOR: 204.p.

${ }^{20}$ HEGEDÜS: 89.p.

${ }^{21}$ KAISER

${ }^{22}$ FODOR: op.cit. II. rész 666.p.

${ }^{23}$ PARÁDI: A Magyar Királyi Csendőrség szervezete. op.cit.

${ }^{24}$ ARTNER - PARÁDI - ZEIDLER: 24.p.

${ }^{25}$ SZLADEK I. rész

${ }^{26}$ Loc.cit. II. rész

${ }^{27}$ KONTRA: A közlekedési csendőrségről.

${ }^{28}$ KONTRA: A közlekedési csendőrség két utolsó esztendeje. 171.p. 1940-1941. évi adatok alapján.

${ }^{29}$ Loc.cit.

${ }^{30}$ Utitárs: 171.p.

${ }^{31}$ KovÁCs-BunA: 762.p.

${ }^{32}$ ÉLTHES: op.cit. 45 p.

${ }^{33} 261$ 340/1929. (XII. 21.) BM.kr. ; Utitárs: op.cit.

${ }^{34}$ AMANT

${ }^{35} 127$ 000/1932. (XI. 28.) BM.r.

${ }^{36}$ A gépjármükerületek székhelyei a következők voltak: Budapest., Budapesti kerület, Debrecen, Eger, Győr, Gyula, Jászberény, Kaposvár, Kecskemét, Miskolc, Nagykanizsa, Nyíregyháza, Pécs, Sopron, Szeged, Székesfehérvár, Szolnok, Szombathely.

TOLDI: op.cit

${ }^{37}$ Loc.cit. 305.p.

${ }^{38}$ KRISTON

${ }^{39}$ Utitárs: op.cit.

${ }^{40}$ 1938./III.tc.

${ }^{41}$ GÁL: 18.p.

${ }^{42}$ BALOGH: I. rész 317.p.

${ }^{43}$ Loc.cit. I. rész

${ }^{44}$ A betétlap mintáját az 74 130/1928. (VI. 12.) KM.kr. vezette be

45 1878/V.tc.

46 1879/XL.tc.

${ }^{47}$ BALOGH: op.cit. II. rész

48247 932/1929. (I. 18.) BM.kr.

${ }^{49}$ KONTRA: A közlekedési balesetek helyszínelése.

${ }^{50}$ SZUT-1927.

${ }^{51}$ REVICZKY 
A jegyzetekben alkalmazott röviditések:

\section{MONOGRÁFIÁK ÉS KISMONOGRÁFIÁK ÉS HASONLÓ JELLEGÜ KÖTETEK}

GÁL

KAISER

PARÁDI: A magyar rendvédelem története.

REKTOR

\section{TANULMÁNYOK}

ARTNER - PARÁDI - ZEIDLER

HEGEDÜS

PARÁDI: A Magyar Királyi Csendőrség szervezete.

\section{CIKKEK}

AMANT

BALOGH

ÉLTHES

FÁBRY

FODOR

KONTRA: A közlekedési csendőrség két utolsó esztendeje.

KONTRA: A közlekedési csendőrségről.

KONTRA: A közlekedési balesetek helyszínelése.

KovÁCs-BunA

KRISTON

REVICZKY

SZLADEK
- GÁl Dániel: Helyszini eljárás. Szombathely, 1939, Martineum. 238 p.

- KAISER Ferenc: A Magyar Királyi Csendörség története a két világháború között. Pécs, 2002, Pro Pannónia Kiadó Alapítvány. 175 p. HU-ISBN 963 907982 0. /Pannónia Könyvek/ HU-ISSN 0237-4277.

- PARÁDI József et. al. (szerk.): A magyar rendvédelem története. Budapest, 1995, Tipico Design Kft. 317 p. HU-ISBN 963046215 X.

- ReKTor Béla: A Magyar Királyi Csendörség oknyomozó története. Cleveland OHIO USA, 1980, Árpád Könyvkiadó Vállalat. 552 p. USA-ISBN 0934214018 .

- Artner Ramóna - PARÁdi József - ZEIDler Sándor: A Magyar Királyi Csendőrség légi, vízi, vasúti és közlekedési szakszolgálati ágai, Rendvédelemtörténeti Füzetek (Acta Historiae Preasidii Ordinis), XXIII.évf. (2013) 27-2829-30.sz. 23-39.p. HU-ISSN 1216-6774.

- Hegedüs Ernő: A Magyar Királyi Csendőrség harc- és gépjármüvei. Rendvédelem-történeti Füzetek (Acta Historiae Praesidii Ordinis), XXIII.évf. (2013) 27-28-29-30.sz. 89-100.p. HU-ISSN 1216-6774.

- PARÁDI József: A Magyar Királyi Csendőrség szervezete. Rendvédelemtörténeti Füzetek (Acta Historiae Praesidii Ordinis), XXI.évf. (2011) 24.sz. 80-90.p. HU-ISSN 1216-6774. A tanulmány korábbi változata 2009. december 3-án Budapesten hangzott el a Szemere Bertalan Magyar Rendvédelem-történeti Tudományos Társaság által szervezett magyar rendvédelemtörténeti tudományos konferenciasorozatnak ,,Csendőrség Ausztria-Magyarországon, illetve Ausztriában és Magyarországon 1849-2005. " címü XXIV. konferenciáján. A tanulmány az előadás javított, bővített és átdolgozott változata.

- Amant Zoltán: A közlekedési rend első nyomai, Csendőrségi Lapok, XXI.évf. (1931) 8.sz. 210-211.p.

- BALogh Béla: Gépjárómúbalesetek okai és azok nyomozása.

Csendőrségi Lapok, XXI.évf. (1931) 12.sz.314-319.p. I.rész.

Csendőrségi Lapok, XXI.évf. (1931) 13.sz. 346-351.p. II.rész.

- Élthes Gyula: A közlekedés új rendje. Csendőrségi Lapok, XX.évf. (1930) 2.sz. 44-47.p.

- FÁBRY György: Kerékpáros közlekedési szolgálat. Csendörségi Lapok, XXI.évf. (1931) 24.sz. 658-661.p.

- FODOR Sándor: Gépjárómüvek a csendőrségnél. Csendőrségi Lapok, XXXII.évf. (1942) 20.sz. 635-637.p. I. rész. Csendörségi Lapok, XXXII.évf. (1942) 21.sz. 665-667.p. II. rész.

- KONTRA Kálmán: A közlekedési csendörség két utolsó esztendeje. Csendörségi Lapok, XXXII.évf. (1942) 6.sz. 170-173.p.

- KonTrA Kálmán: A közlekedési csendőrségről. Csendörségi Lapok, XXX.évf. (1940) 13.sz. 426-431.p.

- KonTra Kálmán: A közlekedési balesetek helyszínelése. Csendörségi Lapok, XXIV.évf. (1934.) 5.sz. 130-134.p.

- KovÁcs-BunA Károly: Hogyan kell ellenőrizni az álló gépjárómüveket és azok utasait? Csendörségi Lapok, XXIII.évf. (1933) 24.sz. 758-764.p.

- Kriston György: A gépjármüvek ellenőrzése. Csendőrségi Lapok, XXIII.évf. (1933) 20.sz. 631-632.p.

- revisnyei REVICZKY Zsigmond: Helyszínrajzok készítése. Csendörségi Lapok, XXI.évf. (1931) 21. sz. 585-588.p.

- SzLADEK Barna: A közlekedési csendőrség Csendőrségi Lapok, XXI.évf (1931) 21.sz. 581-584.p. I.rész. Csendőrségi Lapok, XXI.évf (1931) 22.sz. 609-613.p. II.rész. 
TOLDI

Utitárs

SZABÁLYZATOK

SZUT-1927

KUT-1937.

\section{TÖRVÉNYEK}

1878/V.tc.

1879/XL.tc

1890/I.tc.

1929/XXXII.tc

1938/III.tc.

\section{RENDELETEK}

57 000/1910. (IV. 29.) BM.r.

300 166/1927. (XI. 8. ) BM.kr.

74 130/1928. (VI. 12.) KM.kr.

81 161/1929. BM.r.

247 932/1929. (I. 18.) BM.kr.

250 000/1929. (VIII. 8.) BM.r.

261 340/1929. (XII. 21.) BM.kr.

127 000/1932. (XI. 28.) BM.r.
TOLDI Árpád: Az autó-rendszámtábláról. Csendörségi Lapok, XXIII.évf. (1933) 10.sz. 302-308.p.

Utitárs: János gazda utazása a közlekedési kódex körül. Csendőrségi Lapok, XXV.évf. (1935) 6.sz. 170-177.p.

- Szervezeti és szolgálati utasitás a Magyar Királyi Csendörség számára. Budapest, 1927, Pallas. 387 p.

- Szolgálati utasitás a közlekedési csendörség számára. (Tervezet.) Budapest, 1937, s.n. 50 p.

- 1878/V.tc. a magyar büntetőtörvénykönyv a büntettekről és vétségekről.

- 1879/XL.tc. a magyar büntetőtörvénykönyv a kihágásokról.

- 1890/I.tc. a közutakról és vámokról.

- 1929/XXXII.tc. a közúti közlekedés szabályozása tárgyában 1926. évi április hó 24-én Párisban aláírt nemzetközi egyezmény becikkelyezéséről.

- 1938/III.tc. a rendőri büntetőbíráskodás körébe utalt egyes kihágások tettenért elkövetőinek a helyszínen való megbírságolásáról.

- 57 000/1910. (IV. 29.) BM.r. a gépjárművek közúti forgalmáról Magyarországi Rendeletek Tára, XLIV. évf. (1910) 235-260.p.

- 300 166/1927. (XI. 8.) BM.kr. a vasúti pályán a gyalogközlekedés megakadályozásáról.

Magyarországi Rendeletek Tára, LXI. évf. (1927) 2331-2332.p.

— $\quad 74$ 130/1928. (VI. 12.) KM.kr. a gépjármüvezetői igazolványok mintájának módosítása tárgyában. Csendőrségi Közlöny, XIII. évf. (1928) 14. sz. 121-122.p.

- 81 161/1929. BM.r. az előcsengetős vasúti vonósorompóknál, valamint helyi érdekủ és mellékvasutakon a „Vigyázz, ha jön a vonat", illetőleg „Állj, ha vonat jön" szövegü intőtáblákkal ellátott sorompó nélküli vasúti útátjáróknál a közönség részéről követendő eljárásról.

Magyarországi Rendeletek Tára, LXIII. évf. (1929) 461-462.p.

247 932/1929. (I. 18.) BM.kr. a közlekedési balesetek bejelentésénél követendő eljárás tárgyában. Csendörségi Közlöny, XIV.évf. (1929) 4.sz. 28.p.

- 250 000/1929. (VIII. 8.) BM.r.a közúti közlekedés rendjének és a közútakon a közrend fenntartásának egységes szabályozásáról. Magyarországi Rendeletek Tára, LXIII. évf. (1929) 1278-1384.p.

- 261 340/1929. (XII. 21.) BM.kr. a közúti közlekedésrendészeti szabályzat némely rendelkezésének értelmezéséröl. Magyarországi Rendeletek Tára, LXIII. évf. (1929) 1516-1517.p.

- 127 000/1932. (XI. 28.) BM.r. a közúti forgalomban résztvevő gépjárművek, pótkocsik megvizsgálása, új rendszámmal, igazolólappal ellátása $\mathrm{s}$ a közlekedésrendészeti egységes szabályzat egyes rendelkezéseinek módosítása tárgyában.

Csendörségi Közlöny, XVIII.évf. (1933) 1.sz. 15-21.p.

\section{Mellékletek jegyzéke:}

I.sz. melléklet

A közlekedési csendőrség számára rendszeresített Méray típusú oldalkocsis motorkerékpár.

II.sz. melléklet

Kistollforgós Bocskay sapka.

III.sz. melléklet

A közlekedési csendőrség számára rendszeresített Fiat Balilla típusú járőr gépkocsi.

IV.sz. melléklet

A közlekedési csendőrség számára rendszeresített Steyer Puch típusú járőr gépkocsi.

V.sz. melléklet

A vízi csendőrség szolgálati hajója. 
A közlekedési csendôrség számára rendszeresített Méray típusú oldalkocsis motorkerékpár.

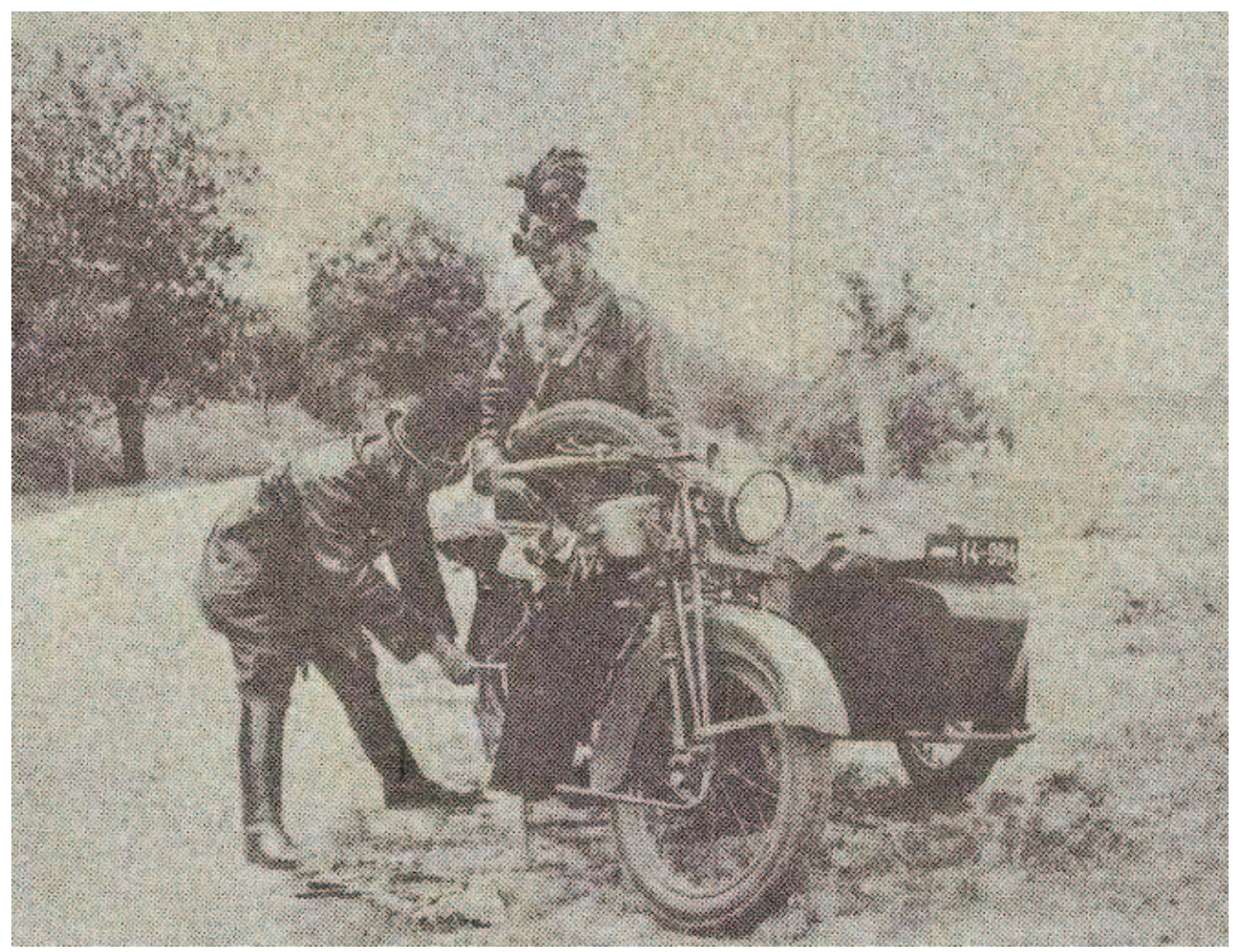

Forrás ! www.csendor.com

II.sz. melléklet

Kistollforgós Bocskay sapka.

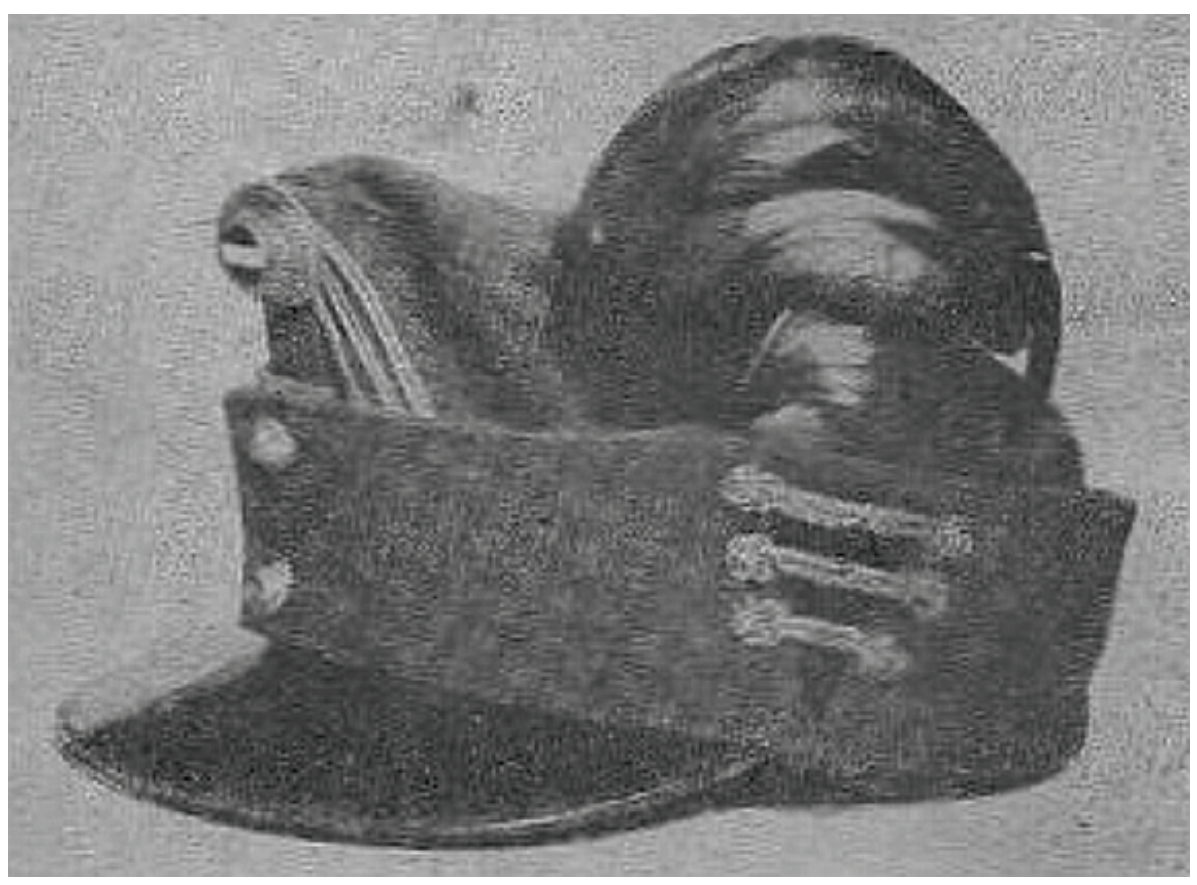

Forrás ! - Csendörségi Lapok, XXXIII.évf. (1943) 19.sz. 583.p.

- 802 355/1943.HM.kr. az új szemernyős csendőrségi tábori sapka viselési módjának szabályozásáról. Csendörségi Közlöny, (1943) 33.sz. 
A közlekedési csendőrség számára rendszeresitett Fiat Balilla típusú járőr gépkocsi.

III.sz. melléklet

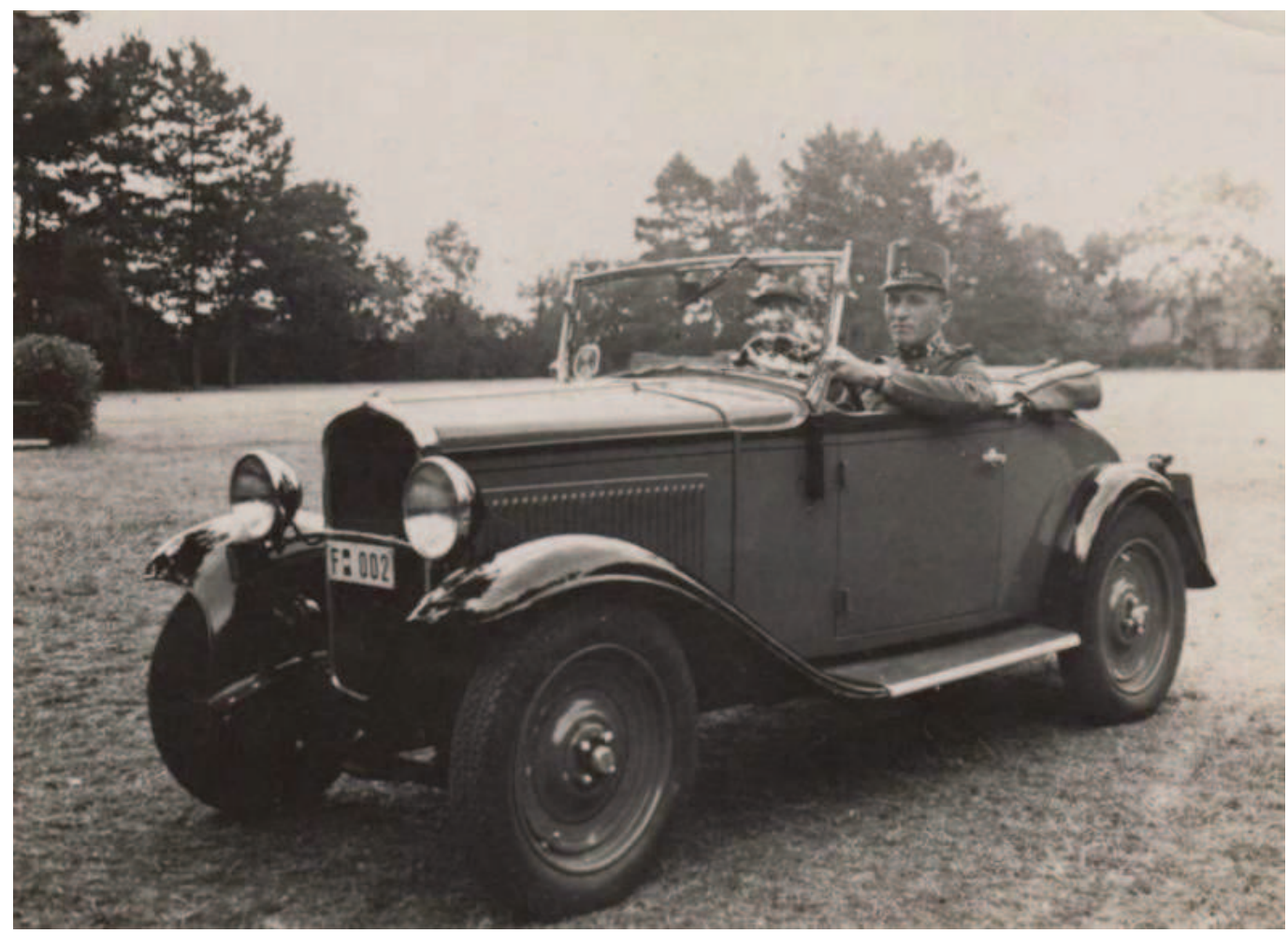

Forrás ! www.csendor.com

A közlekedési csendőrség számára rendszeresített Steyer Puch típusú járőr gépkocsi.

IV.sz. melléklet

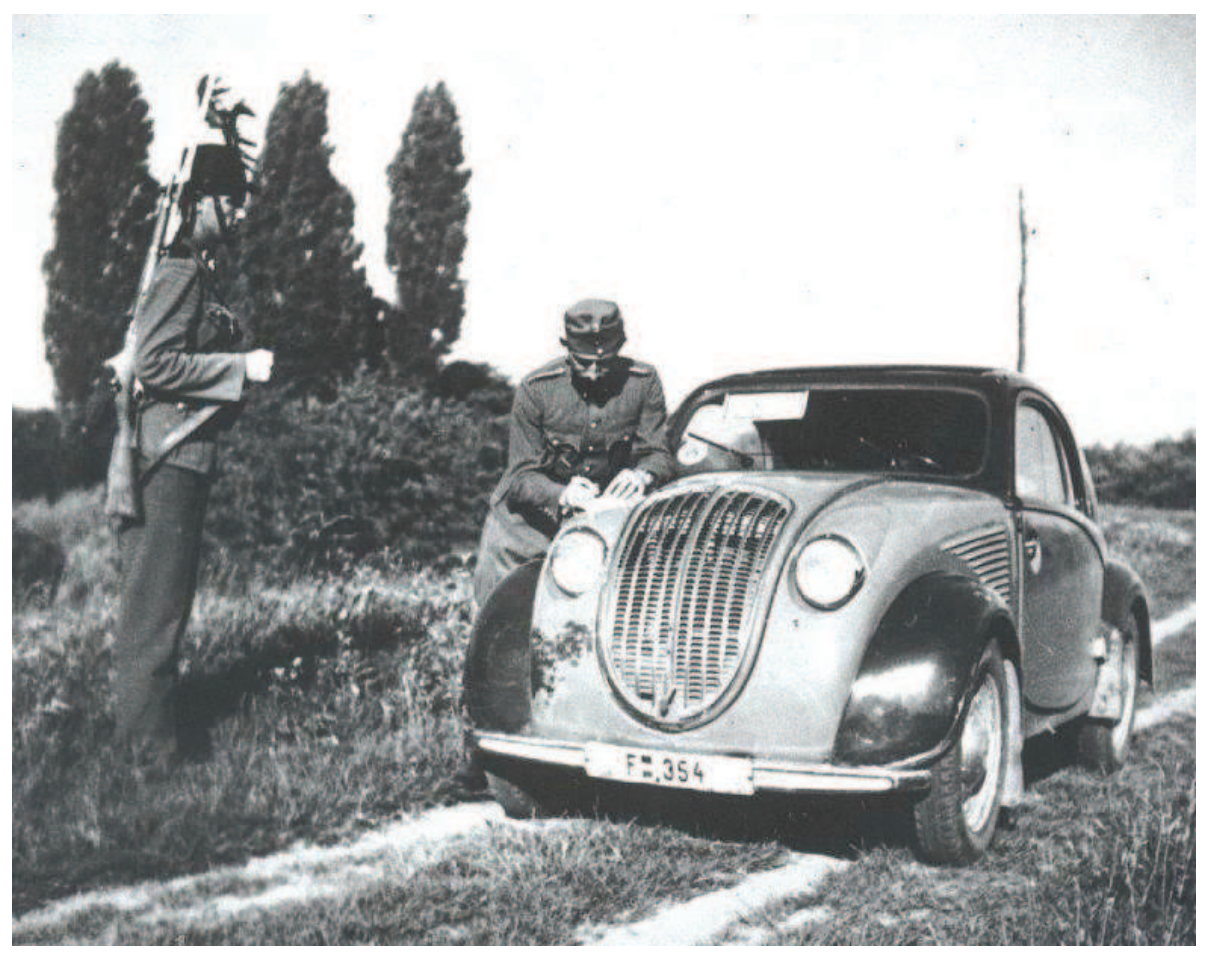

Forrás ! www.csendor.com 


\section{A vízi csendőrség szolgálati hajója.}

V.sz. melléklet

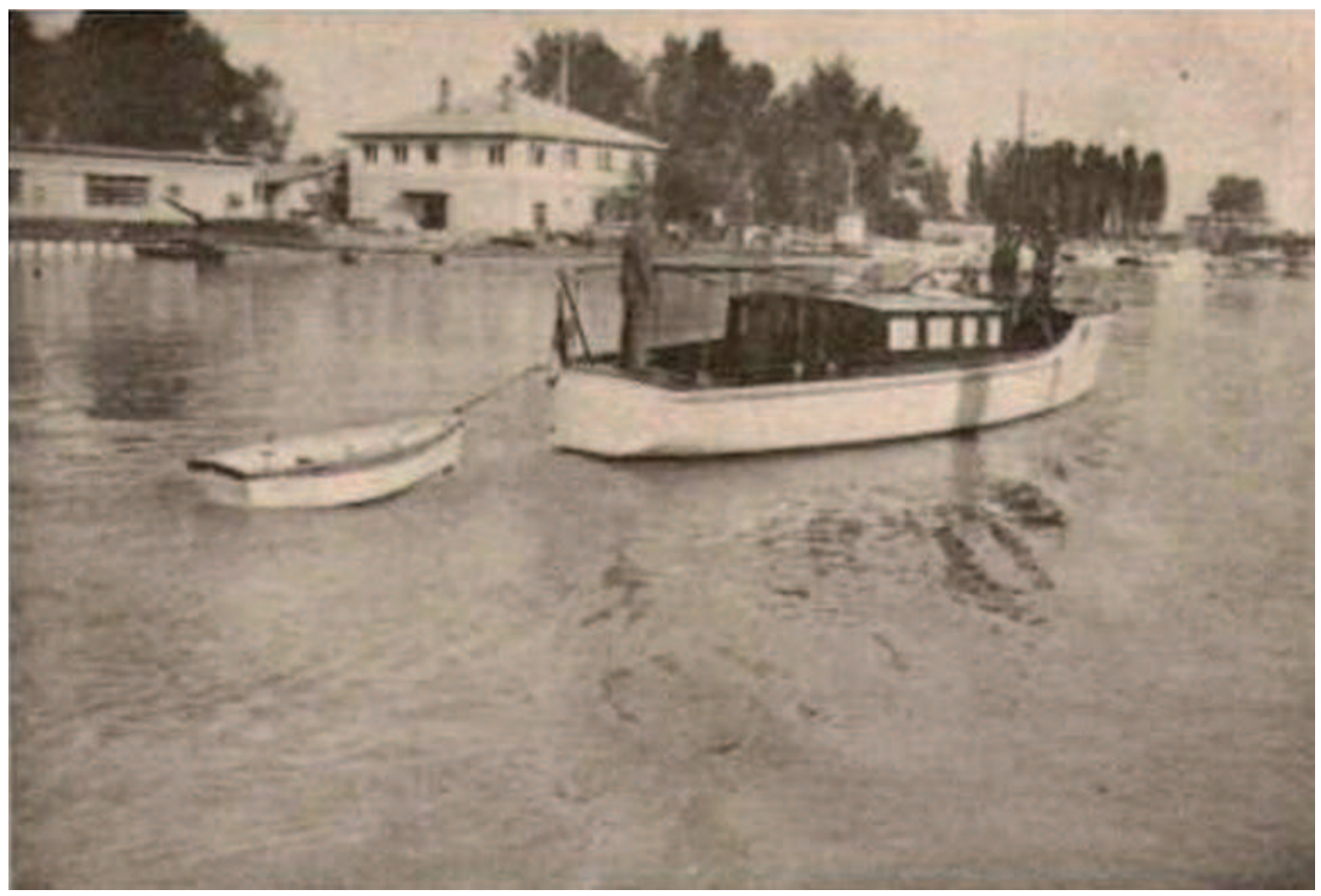

Forrás ! www.csendor.com 